$$
\begin{aligned}
& 7 / 3196 \\
& \text { MORKSHOP IN POLITICIAL THEOPY } \\
& \text { AND POLICY ANALYSIS } \\
& 513 \text { NORTH PARK } \\
& \begin{array}{l}
\text { INDLANA UNIVERSITY } \\
\text { BEOOMINGTCN, PNDIMNA 47405-3186 }
\end{array} \\
& \text { Reprint Files--CPR }
\end{aligned}
$$

\title{
Changing Economic Problems for Women in the Nile Perch Fishing Communities
}

\author{
on Lake Victoria
}

\author{
Modesta Medard \\ Tanzania Fisheries Research Institute \\ and \\ Douglas C. Wilson \\ Rutgers University
}

Paper to be presented at the Annual Meeting of the Society for Applied Anthropology, Baltimore, MD 27-31 March, 1996. Please direct correspondence to the second author at Ecopolicy Center, Continuing Education Annex, Box 270, Rutgers University, New Brunswick, NJ 08903 DWILSON@AESOP.RUTGERS.EDU 
Introduction

Unknown persons introduced an exotic fish species, the Nile perch (Lates nileticus), to Lake Victoria in the 1950s, and in the late 1970s its population suddenly exploded. The piscivorous Nile perch decimated most other fish species, and as many as 300 may have become extinct (Barel 1986). In combination with fishing pressure and changes in water chemistry (Bundy and Pitcher 1995), these events transformed the lake's fisheries. Where once there were many kinds of fish, now there are only three commercially important species: the Nile perch, one species of tilapia (Oreochromis niloticus), and the sardine-like dagaa (Rastrineobola argentea).

These changes vastly increased the value of fish production, and the number of fishers in the Tanzanian portion of the lake increased $46 \%$ between 1980 and 1986 (Reynolds and Greboval 1988). Tanzanian fishers christened the Nile perch the "savior." Over fishing has been a problem on Lake Victoria since the beginning of the century (Dobbs 1927) and the lake was badly depleted in the 1970s. During the 1980s the Nile perch meant a new source of inexpensive protein for people around the Tanzanian shoreline.

The Nile perch is a large, white, meaty fish that finds a ready international market. An industrial processing and export industry grew up in Kenya and Uganda during the 1980 s and in Tanzania in the early 1990s (Reynolds et al. 1992). The fish are exported as frozen fillets from processing plants on the lake shore. The export industry has driven up the price of Nile perch and led to an increase in capital investments in fish harvesting equipment. The demand generated by the filleting plants is huge and growing. The degree to which this demand is felt varies in different parts of the lake. They are 
swiftly expanding their capacity for collecting fish by boat rather than truck, which deepens their penetration into isolated areas.

For the people living beside Lake Victoria these changes represent a vast alteration in their human ecology. The present paper focuses on one important aspect of this alteration - the impact of these changes on women. It presents a broad sketch of what is happening, rather than an in-depth analysis of changes in a particular village or region. We gathered the data during series of two to three week visits in nine fishing communities on the Tanzanian section of the lake in 1994 and 1995. Besides a formal survey, individual and group interviews were done with local women. We focused the qualitative research on women involved in small businesses.

\section{A Critical Approach to Human Ecology}

When we approach Human Ecology from a critical perspective, the central question is how responses to ecological change result from the interaction of groups possessing different amounts of social power. We can broadly understand these responses as new rules and institutions governing interaction with the environment. As the environment changes, new institutions are created and made effective through processes of legitimation, surveillance and discipline. One crucial aspect of such an analysis is the role that gender plays. If differences in social power determine how society will response to changes in natural ecology, then these changes will have different implications for men and women.

Ecological changes are intertwined with political and economic changes. For the populations living near Lake Victoria, changes in all three of these categories have always left women relatively more disadvantaged than they were 
before the change. At each juncture, the new "rules of the game" have served those who were in positions of advantage when the changes began.

A good illustration is change in rights to land. Okeyo (1980) charts how colonial authorities "reformed" the traditional, corporate, clan-based land tenure system of the lake-side Luo people to reflect the male head-ofhousehold model. Later, in the 1970s, Kenyan adjudicators believed that widows, and women who had only daughters, did not need as much land as families with men.

Another example is large-scale "development" schemes. In development's mass armies, the enlisted women have done most of the marching while the other half of the population often formed a bloated officer's corps. In Tanzania, women were the losers during the ujamaa villagization scheme. They were deprived of their traditional claims to land in favor of men and village leaders, while their participation in village planning was restricted because they were not "heads-of-households." That was just as well, because their work loads left them with no time to spend in endless village debates (McCall 1987).

East African women have not been passive. Mbiliyi (1990) observed an increased resistance among women to patriarchal social relations. Women are refusing to work on family land and going to neighbors' lands instead. Women and children mounted a successful tea picking strike in Rungwe. Local organizing is providing a less dramatic, but still effective, strategy for increasing women's power. Women are finding ways of circulating cash and labor among themselves. These are the two most important constraints that they face (Thomas 1988). They do so in a ways that help them respond to immediate needs, thus giving them more flexibility in meeting economic and ecological changes. 
A critical approach to Human Ecology recognizes that responses to ecological change are the products of interaction within tangible social networks, i.e., people talking and bargaining with one another while making practical decisions. Central to the ecological nature of the analysis is that these interactions take place in concrete time and space. Particularly important are the "back and front regions" (Giddens 1984) which influence potentials for the surveillance of behavior and the enforcement of rules and institutions. These regions are, in turn, often a function of geographical scale and physical proximity.

Men's physical absence while at sea and their economic dependence on the women who process and trade the fish is an important aspect of the situation of women in many fishing communities (Thompson 1985). The dependence, however, ' stems from the absence. It is the physical absence of the men, and their reduced inability to surveille the women's processing and trading activities, that underlies their economic dependence. On Lake victoria, this absence has not had the effects that Thompson (1985) documents in other fishing communities. Small-scale fishing does not usually take the form of a husband and wife collaboration that is so common elsewhere. The spatial dimension, however, remains crucial here in other ways.

spatial (and temporal) scale is a central organizing principle of a human ecological analysis. Rules and institutions emerging from struggle between groups of differing social power determine responses to changes in natural ecology. The processes of legitimation, surveillance, and discipline that ground these institutions are all affected by scale. To understand in concrete terms what the ecological changes in Lake Victoria have meant to the 
lake-side women, we need to analyze them at three relevant spatial scales: the lake, the community, and the household.

\section{The Lake}

General changes. In surface area, Lake Victoria is the second largest freshwater lake in the world after Lake Superior. Three countries share it: Kenya, Uganda and Tanzania. The Tanzanian section is the largest with 51 percent of the lake's surface. The lake is situated on a plateau between the two East African rift valleys. In contrast to other, nearby lakes situated within the rifts, Lake Victoria is shallow with a mean of 20 and a maximum of 79 meters depth. One result of this shallowness is that it is an extremely rich source of nutrition. The lake basin boasts a human population estimated as high as 20 million people (RTF2 1995). In some areas the population density is among the highest rural densities in the world.

The biological causes of the changes in Lake Victoria are disputed. The Nile perch introduction happened in the 1950s, but, mysteriously, the population eruption did not happen until the late 1970s. Concurrent with the growth of the Nile perch, scientists have observed a depletion in the level of dissolved oxygen in the water. Most biologists had believed that Nile perch caused this change by eating plant-eating fish, which led to greater overall biomass and greater oxygen depletion when all this biomass rotted. More recent work has suggested that runoff from agriculture and sewage caused the drop in levels of dissolved oxygen. This in turn, made a certain shrimp, that is a preferred source of Nile perch food, more available. This new source of food

The importance of international and national markets mean that these scales are also cruclal. A tractable paper, however, requires that theır relevant aspects be addressed at the scale of the lake. 
is argued to be the cause of the Nile perch population explosion (Bundy and Pitcher 1995).

Lake-side people had many different kinds of fish available to them before 1980. The most abundant were various species of haplochromis. They are edible, but small and bony - think of eating aquarium fish, which many of these species are. Catching haplochromis with woven traps was women's work and they were always available as a source of protein when more appetizing options were not. Men caught lungfish, tilapia, catfish, and other larger species. Women processed these fish using traditional technologies as part of an active regional and national trade.

These people responded swiftly to the advent of the Nile perch through new fishing practices, shifts in labor, and investment. Employment on the whole lake, including ancillary activities, rose from 158,000 people before the Nile perch to a level of 422,000 people by 1992 , the peak of the Nile perch fishery. Earnings per fisher increased by $\$ 473.00$ per year adjusted for inflation, a significant sum in Tanzania (Reynolds et al. 1992). Fishers sent more of their catch to central markets, particularly the central market at Mwanza, which handles $90 \%$ of the legal trade to distant markets (Maembe 1990). Sun dried dagaa has also undergone a recent explosion in exports to neighboring countries (Reynolds et al. 1992).

Small-scale fishing boats generate almost all of the fishing effort on the lake. These fishers use plank-keel canoes taking a total crew of two to five people. Owners of boats are commonly involved in beach activities, e.g., selling the catch; although, especially on the more commercialized beaches, they rarely fish themselves. An increased separation of ownership and management of fishing units has accompanied the new fishing patterns (Harris 
et al. 1995). Ever more small-scale fishers are receiving loans from largescale processors who are competing to guarantee supplies.

Effects on women. As early as the late 1980's, before any major incursion by the international market, Leendertse (1990) observed that women were being increasingly marginalized in the fishing industry. Women had remained in the smaller scale, less remunerative processing of traditional species, while the newer technologies associated with the Nile perch were dominated by men.

One reason was the oiliness of the Nile perch. The fat produced when this fish is smoked or fried is much more than the amount produced by the traditional species. This meant that smoking kilns for the new fish had to be larger and use more fuel. This increase in capital costs was a barrier for women trying to enter the Nile perch smoking business. Low capital means lower quality fish with a shorter shelf life.

Another reason was that new, and more remunerative, marketing channels arose for the Nile perch. Men dominated these new channels and informal barriers limited women's access. This is beginning to change. While the nearlake trade in fresh Nile perch is the province of young men on bicycles, many women are involved in a large and growing regional trade in smoked Nile perch. In fisheries around Africa, commercialization of traditional fishing has pushed women from part time participation to exclusion (Scudder and Connolly 1985). The Nile perch processing factories can afford to pay higher prices, making it much more difficult for women, and other small traders, to get fish. A significant amount of fish is not acceptable to the factories, mainly because their sizes are small. These leavings are available for smoking, which requires significant capital and is usually done by men, and for other kinds of processing which do not require as much capital, and are done by both men 
and women. Salting, sun-drying, and frying fish are the types of processing

that are widely available to women on these beaches.

Recent management measures are bound to have a negative affect on women.

All nets with a mesh size of smaller than 2.5 inches have been banned. This

includes beach seines, which are an important source of the smaller fish that

women use. Beach seines are very large, labor intensive nets that are pulled

into the shore. They often use local children as pullers in exchange for some

fish. This makes then an important avenue of access to the resource for

families who do not work on fishing boats or own fishing gear (Wilson and

Medard 1996). These management measures are needed from the perspective of

having a sustainable resource, but their impact will be felt

disproportionately by women and poorer households.

Of all the beaches we visited the one most deeply penetrated by the

international Nile perch market was Rubiri Island. Mama Nne's story is

illustrative of the difficulties that the penetration of the international

market has created for women.

Mama Nne first came to Rubirl in 1992 just when it was beginning to become an lmportant flshing center. She had investment capital of $\$ 60.00$ with whlch she intended to begin a tea shop. She decided to begin fish processing after she arrived on the island, malnly because of the difflculty she was experiencing getting supplies for the tea shop to the island at reasonable prices.

Mama Nne decided to salt and dry Nile perch. In 1992 the fish were plentıful and cheap. Beginning in 1993 ever more collection boats were arriving on the lsland from the fish processing factories in Mwanza town. The factory agents began to bulld direct ties to the fishers; they offered hlgher prices and gave them fishing gear, engines and fuel. Mama Nne, along wlth other local and regional fish processors, is only able to get fish that the factory boats reject. Going entire days without being able to buy anything is common. She sometimes travels by hired boat to other islands to find fish, but this is risky because the lake in that area is very open and rough. Most of the women fish processors on Rublrl Island are single women with no other means of support. Mama Nne says "I don't know what kind of business I can do, the poor continuing to lose while the rich get more and more." 
The difficulties women face are not only derlvatıve of thelr economic disadvantages. Men will actively resist women's participation in sectors where they see them as a competitive threat. They put pressure on fishers not to sell to women. On one landing beach women complained to us that men use their easier access to short term credit to keep them from gettıng fish. Men physically block women from access to fish (Masalganah 1992). We heard several reports of demands for sexual favors in exchange for business access.

Two other areas of the Nile perch trade have been avallable to women but are now threatened. The first is trade in sun-dried swim bladders. These bladders are used for soup in Asla and in beer brewing in Europe. Thls had been a minor, ancillary trade and many women moved into it in the late 1980 s (Bwathondl and Mosılle 1988). Prices for these bladders rose steeply in the early 1990s; our survey of smaller fish traders found them to be the major source of profit. Men seem to increasingly dominate activities in this sector.

The other area is the fryıng of fish "racks." These are the head and skeleton of the fish that is left after fllleting in the processing factorles. They sell these racks very cheaply to local women who fry them and sell them In neighboring villages where they are popular. Currently, there ls a move by large private concerns, supported by the government and international agencies, to use these racks to make fish meal. Some technıcal difficulties have slowed this effort, but it seems inevitable that women will lose this source of Income and inexpensive protein as well.

It seems that when sectors of the flshing business are considered anclllary and minor they avallable for women. If changes in prices or avallablitty make these sectors more attractive, then women have more dıfficulty partıcıpating. In addıtion, flsheries management measures threaten women's access to the fish resource. 


\section{The Communities}

Fishing communlties are not alıke. One important difference on Lake Victorla is the degree to which a community is part of the network for gatherıng fish for the international market. These communities have many full time fishers, who are more likely to be temporary residents. These mugrants, and the minority of local fishers who can take advantage of new opportunities, are the beneficiarles of an lncreasıng income gap among fishers (Wilson and Medard 1996).

A more diversifled household reproduction strategy marks those villages that reman isolated from the international market. The fishing 1 s less capıtal intensive and more seasonal. Women's particlpation is often in response to speciflc needs for cash, rather than a full time business. The way lake-side women are blocked from participating in formal, community level life has been a major factor in their oppression. Women are often able to make decisions about their own farms and famllies, but at the village level thelr partıcıpation is very limited (Fortemann 1979). Few women at the local level are members of the Chama cha Mapınduzl, the recently exrulıng party. Most of the "mabalozl," party 10-cell leaders who play a very important role in local life, are men. Thls communlty-level disadvantage ls not absolute. A few women hold lmportant posts in local government.

Women's groups. The ex-ruling party has its own national women's group with branches in the villages. In all the communities that we visited we found that these local branches have become moribund. So completely have they defined the idea of women's groups, however, that new structures have been very slow to replace them. Ineffective, and at tımes manıpulatıve, outside leadership, which has been a problem for women's groups throughout East Afrıca (staudt and Col 1991, Udvardy 1988), has been an obstacle around Lake Victorla as well. Clan rıvalrıes are another hındrance to organization in some areas (Gerrard 1990, Masaiganah 1992). 
Around the lake "most groups were organized in the atmosphere, and they are not strong" (Masalganah 1992). An experıenced organizer told us the story of one group that did not work out very well. A church organized them. They decided to try to overcome the cultural bias agalnst women fishing on open waters, although there was no great desire for this expressed by the women. Perhaps the church group thought that the women's negative attitude toward going fishing would not be very strong - since the community was located miles away from the lake (Masalganah 1992).

In the villages we visited, we found that a general distaste for collective economic action has surfaced as a reaction to the excesses of the ujamaa perıod. This is true of both men and women. Women want to work on their partıcular enterprise as individuals, although they are still willing to come together for common logistical support such as transportation. Gerrard (1990) described the woman's fish tradıng system as "one woman - one unit of trade," but pointed out that they still cooperate, helpıng and teaching one another. Attempts to manage common property, such as a commonly owned fish smoking kilns in Sote (Gerrard 1990) and Igombe (per. obs.), have not been successful. Women's revolving credit groups are now beginning to emerge in the area, partıcularly near Mwanza, but have had a slower start than in other parts of Tanzania (Leendertse 1990). We found only one group of women, on a beach near Mwanza town, actıvely pursulng this strategy. Women are generally distrustful of credit, although as a group they are a much better credıt risk (Masalganah 1992). They may also be distrustful of talkıng about credıt, hence introducing a downward bias into our own observations.

Fishing communities along the lake shore fit into two Ideal types - the settled village in which mainly local residents fish, and the fish camp where fishers live in temporary accommodations. These ldeal types should not be drawn too starkly. In the settled villages fishing is a very important part of reproducing those households that fish. Symmetrically, the same individuals 
often inhabit fish camps for extended perıods, cultivating gardens and nearby fields. Of the communities that we visited, five are settled villages with active fishing, two are entirely fısh camps, and two are settled villages that contaln fish camps.

Life for women in fish camps varles. The two fish camps we visited are very different sorts of communities, but they are alike in one cruclal demographic respect: the vast majority of both populations are young men. It is this shared fact that makes their contrast so starting.

One of the two fish camps is Rubirl, which is very crowded and urban. It is an Island half a kilometer across and a kilometer long that holds at least 1000 people. It is more reminıscent of the gold mining camps near the lake than of the other fishing settlements. The island has only one latrine and the sanıtary situation is unpleasant. Fishers on Rubırı sald that the island attracted trouble makers. Rubirl is very nolsy at night, with many bars and carousing young men. Durıng the three weeks we were there, there were several fights, and severe public beatıngs of miscreants by the village government. Although a few fishers had famlies with them, most sald they would never bring their wives to a place like Rubirl. Many women on the island are single and come to provide various services for the fishers.

Nkome 1 s just as much a fish camp as Rubiri is. The bulldings are all made of temporary materials save for one small store, but several famlies live there together. Nkome is much cleaner than Rubirl. The sanıtary infrastructure that someone famlliar with rural East Africa would expect to see, such as dish racks and latrınes, is in place. An elderly respondent on a nearby farm related that the fish camp used to be seasonal and fishers would come without their families. He said, in fact, that women had been prohıbited. In recent years the camp has become year round, famllies are present, and tencell leaders, rather than just beach leaders, have been chosen.

The striking difference is at night. Nkome is much quieter. There is still a great deal of drinking, but it does not become carousing. We saw no 
serlous fights or punishments. The women told us that the young men consistently treated them with respect. One sald that she had been surprised, but that the way she was treated on Nkome was no different from "in a village."

We made the relatıve peace of Nkome the toplc of several conversations with residents, some of whom thought it remarkable as well. The boat owners claim most of the credıt, and may be justıfied in doing so. They see themselves as responsible for the behavior of their young crew. Some boat owners had brought the crew from distant homes and say that they must answer "to their fathers." One large difference is that on Rublrl crew members are much less likely to be related to the boat owner. Only one (3\%) of our sample of 36 Rubiri crew members was a relative of the boat owner, while on Nkome it was 28 percent, a figure that suggests that there is a good chance that at least one member of a boat's crew will be a relative.

\section{The Households}

Female-headed Households. Female headed households are disproportionately represented in the fishıng industry. This was found true in Kenya (Yongo 1991) and in Tanzania, where it is partıcularly the case for women over 40 (Masaiganah 1992). The reasons for this are not mysterıous. Smith and steven's (1988) Investigation of female-headed households in the Bukoba area found that these households have severe agricultural disadvantages: smaller plots; Insecure tenure; less access to hlred labor, agricultural inputs and information; and fewer opportunities to generate capital. We found no significant difference in the average number of dependent children (3) or the average years of education (also 3) between women in female-headed and coupleheaded households. Fish tradıng is an opportunlty for divorced or deserted women in a region where they have limited property rights (Croll 1981). Of the 195 women in our sample, 22 were dlvorced or separated; of those, one got $\$ 50.00$ and the rest got nothing. 
Table one ${ }^{2}$ describes the type of non-farm activity engaged in by women from female-headed households. The fish related activities are trading and processing fish, and in one case owning a boat. All the traders were independent, but flshers employed seven of the processors to sun dry dagaa. The other off-farm activitıes were of various types. They included running small tea shops, cooking and selling rlce cakes and other snacks, and runnıng small shops. Fish-related activities clearly provide an important opportunity for these women. While they particlpate in other types of off-farm actıvitıes In proportion to their overall number in the population, they are underrepresented in agriculture, and they are over-represented in fish-related work.

TABLE ONE: TYPE OF OFF-FARM ACTIVITY ENGAGED IN BY WOMEN BY TYPE OF HOUSEHOLD

\begin{tabular}{|c|c|c|c|c|}
\hline & \multicolumn{4}{|c|}{ TYPE OE OFF-EARM ECONOMIC ACTIVITY } \\
\hline & FISH RELATED & $\begin{array}{l}\text { NOT EISH } \\
\text { RELATED }\end{array}$ & $\begin{array}{c}\text { ONLY } \\
\text { EARMING }\end{array}$ & All \\
\hline $\begin{array}{l}\text { FEMALE-HEADED } \\
\text { HOUSEHOLD }\end{array}$ & $35 \%$ & $11 \frac{9}{0}$ & $7 \%$ & $12 \%$ \\
\hline MARRIED WOMEN & $65 \%$ & $89 \%$ & $93 \%$ & $88 \%$ \\
\hline $\mathrm{N}$ & 26 & 63 & 101 & 190 \\
\hline
\end{tabular}

Mama Mwılı and Mama Tatu's storıes lllustrate how much flexibılıty a single woman needs to make a living by Lake Victorla. They have to be able to shift from one way of surviving to the next. Fish related activities provide several optıons - and, so, make a major contribution to this flexibility. Men still dominate these activities. As the following stories illustrate, thls domination, in combination with the basic geographical facts that make flshing

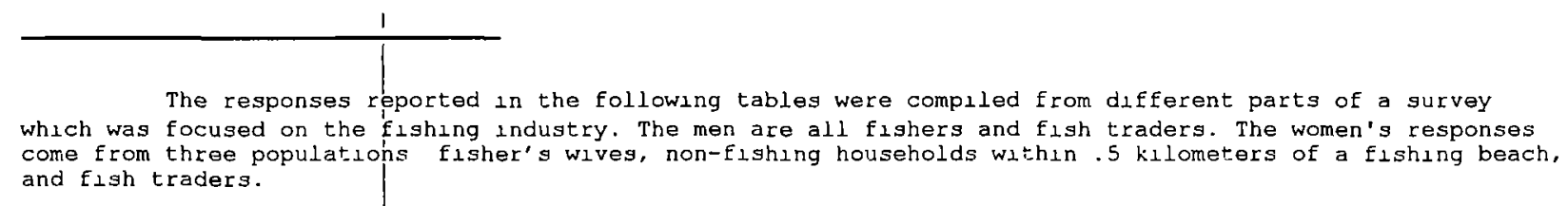


such a difficult thing to surveille, can make fish-related activitıes a

dangerous option for women.

Mama Mwllı lives in Guta, a beach on speke Gulf that is central to the fish trade. She was married from 1961 through 1979 when she divorced. The reason she gives for the divorce is that her husband was not happy with her chronlc poor health.

Mama Mwill moved to Guta after her divorce and began to support herself by making "local brew" an inexpensive mead. Within a year she began to invest in fishing gear. She bought twane and made two fishing nets that she gave to a fisher in return for a share of the catch. She quickly discovered that thls was a difficult arrangement to enforce. The man to whom she was renting the gears was selling the catch to other fishers on the lake and underreporting the catch to her.

She decided to buy hooks and a line and hire a new flsher to work with her besides the old one. This arrangement seemed to work for the first year, but then the first fisher reported that they had stolen her nets. Not long after this, the second reported that her hooks and line had been lost in the water. This was the end of her flshing. Mama Mwlll turned from fishing to processing fish, processing cassava, and carrying these items to sell in distant markets.

Another woman in Guta who became involved directly in fishing Is Mama Tatu. She was born in 1946 and marrled at the age of 12 . She suffered two stillbirths before finally glving birth to her first child after 14 years of marrlage. After having this one son she was unable to have any more children. Her husband divorced her because of this infertility, combined with general lll health.

Mama Tatu is involved in many enterprises. She farms. She bullt three houses with money she earned from selling cotton and now rents two of them. She also sells cassava and maize flour and smokes flsh. She became involved in fishing when she convinced her grown son, who was workıng in Dar es Salaam, to send her ten fishing nets. This was in 1992, just after the profitabllity of the Nile perch flshery had peaked. She supplied her nets to a fishing boat in return for a share of the catch. After four months the boat owner told her that flve of her nets had been stolen.

She decided that she would employ her brother's son to help her with the fishing. She brought him to stay in her house and work on her remalning nets. The young man was unreliable, he would fish but then refuse to glve her the proceeds, sometimes he would come home with nothing. Her experlences with flshing have led her to decide to concentrate on farming. In spite of the danger of drought, she feels that fishing is too unpredictable.

Couple-headed Households. Households around Lake Victoria are fluid entıties

with constant movement in and out of people sharing various relations. Cowlves often live together in a homestead, a complex called an mji in swahılı.

Allocation of land is commonly in the hands of the husband/father, but there 
are also mji lands on which people from each household work (Kazimoto et al. 1990).

One surprising result is that, unlıke many other fishing communitıes around the world, flshing enterprises on Lake Victorla do not commonly Involved husbands worklng wath their wives. We found no significant relationship between a woman being the wife of a fisher and her being engaged in fIsh-related businesses.

Our data show husbands getting the money from $83 \%$ of the economic actıvıties in which women partıcipated. Thıs ıncludes agrıcultural activitıes but does not differentıate types of agricultural activities. When wives control their own resources they must spend their money on the household, whlle husbands are not so constralned (Potash 1985, Safilos-Rothschıld 1990, Smlth and Stevens 1988).

Women do most of the fleld work and are involved in many practical decisions about the household and farm (Fortemann 1979). In our survey we asked respondents about who decided household issues. These responses are reported in Table Two. 


\begin{tabular}{|c|c|c|c|c|}
\hline \multicolumn{5}{|c|}{ TABLE TWO: PERCENTAGE WHO DECIDE. } \\
\hline \multicolumn{5}{|c|}{ WOMEN'S RESPONSES } \\
\hline The person who decides..... & Husband & $\begin{array}{l}\text { Both } \\
\text { together }\end{array}$ & Wrfe & $\mathrm{N}$ \\
\hline what food will be cooked. & 58 & 31 & 11 & 163 \\
\hline $\begin{array}{l}\text { what business ventures the wife wlll } \\
\text { pursue. }\end{array}$ & 45 & 41 & 14 & 163 \\
\hline what crops to plant. & 30 & 56 & 14 & 162 \\
\hline children's educatıon. & 31 & 62 & 7 & 135 \\
\hline children's punishment. & 25 & 68 & 7 & 137 \\
\hline helplng relatives. & 23 & 70 & 7 & 163 \\
\hline \multicolumn{5}{|c|}{ MEN'S RESPONSES } \\
\hline what food will be cooked. & 60 & 33 & 7 & 123 \\
\hline $\begin{array}{l}\text { what business ventures the husband } \\
\text { wlll pursue. }\end{array}$ & 65 & 32 & 3 & 134 \\
\hline what crops to plant. & 36 & 57 & 7 & 133 \\
\hline children's education. & 44 & 56 & 0 & 119 \\
\hline children's punishment. & 22 & 69 & 9 & 111 \\
\hline about helping relatives. & 28 & 71 & 1 & 133 \\
\hline
\end{tabular}

What is interesting is the remarkable extent to which the responses converge. While only 14 responses descrlbe the same household, equivalent numbers are remarkably close. The statistically significant differences are that men do not report that their wives are the sole decusion makers in matters of crops, children's educatıon, and helping relatıves, to the same extent that women do. The only other difference is that more men see themselves as sole decision makers about the children's education. Even these differences are not large. What these data reflect are the lake-side people's expectatıons about these decısion-making processes.

These data do not necessarlly reflect the decision making patterns in particular households. At the level of individual households the data in Table 
Two lose their focus. As these relatıonships are created across time in concrete, day to day decisions, the categorles lose the definition they have when the questions are abstractly placed. Survey questions and answers are a discourse. They are not the same discourse as deciding what will be for dinner. A wlfe may not ask her husband what he wants for dinner after he has Just been a jerk about what crops to plant. This does not mean that they are not able to reveal what they see as a general pattern in response to a question.

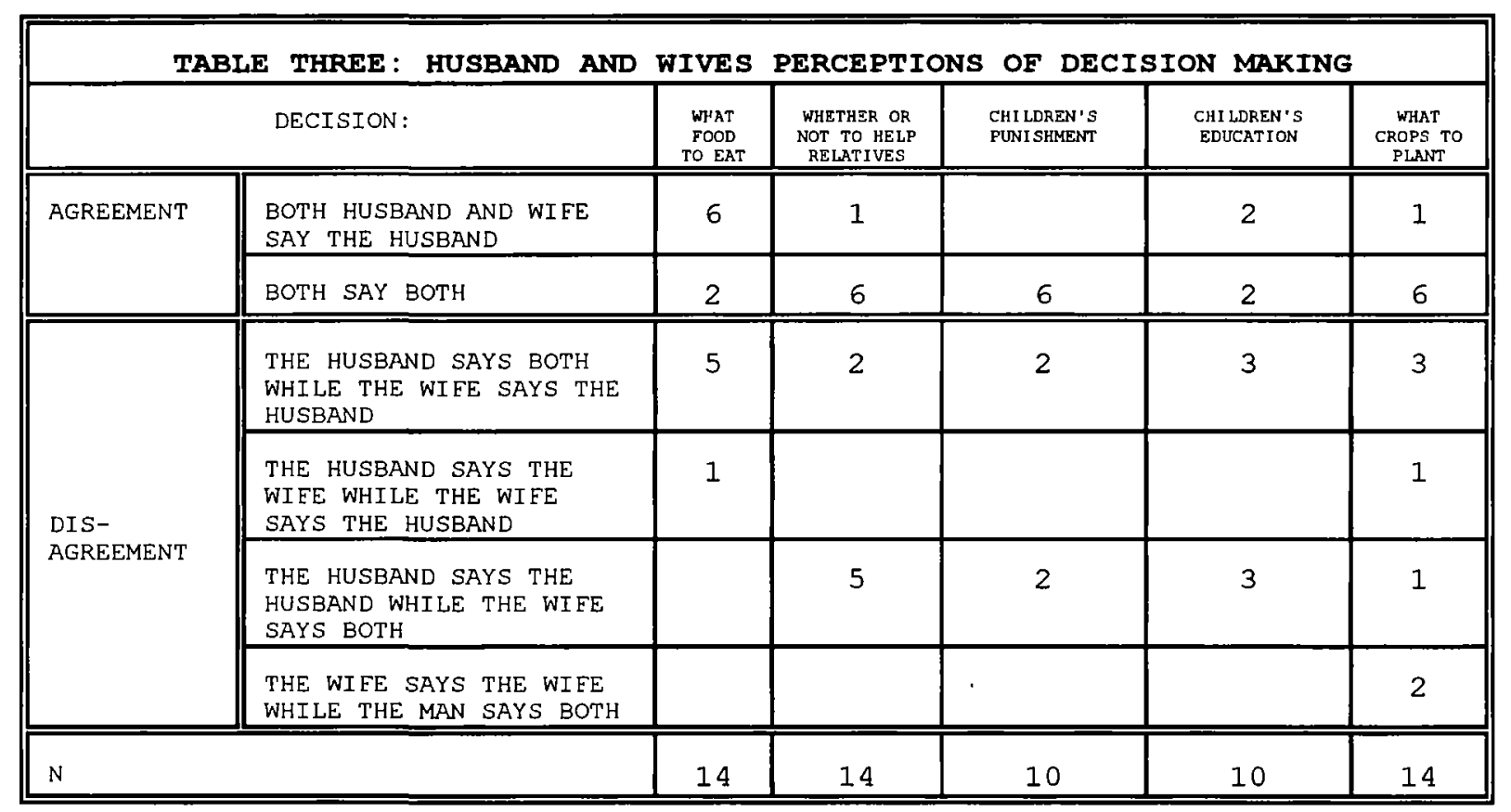

Table Three reports the responses of the 14 couples that were describing the same household. The couples' constructions of their own households' decision making processes agree about half the time. We include Table Three because the patterns it shows are Interesting, but what we can Infer from the responses of 28 people is limlted. The simple average of agreelng half the time is repeated flve times. Calling lt a rule of thumb would be safe. Three patterns never emerge, and we can infer that they are rare. One of these is one of three possible forms of agreement: both people never agree that the wife is a sole decision maker about some arena. We never see two of the six 
possible forms of disagreement: the husband says the husband while the wife says the wife, and the husband says the wife whlle the wife says both. Tables Two and Three indlcate a norm that most decisions are to be made by the couple together, but women's particlpation is still considered, particularly by the men, to be at men's sufferance. When we combine the data in the tables with discussions and observations in the villages, what emerges is a cultural transition. The expectation of male domination is being challenged, and women's status in the household is slowly shifting.

\begin{tabular}{||l|c||}
\hline \multicolumn{1}{|c|}{ TABLE FOUR: SOURCES OF FUNDS FOR WOMEN'S BUSINESS VENTURES } \\
\hline \multicolumn{1}{|c||}{ SOURCE } & PERCENTAGE CITING SOURCE \\
\hline HUSBAND & 51 \\
\hline NO ONE & 33 \\
\hline FEMALE RELATIVE & 8 \\
\hline FEMALE ERIEND & 3 \\
\hline PARENT (S) & 1 \\
\hline MALE RELLATIVE & 1 \\
\hline MALE FRIEND & 1 \\
\hline GROUP & 1 \\
\hline LOCAL CCM OFFICIAL & 1 \\
\hline \hline N TOTAL NOMBER OF DIFFERENT SOURCES OF HELP CTIED BY WOMEN \\
REGARDLESS OF NUMBER OF BUSINESSES)
\end{tabular}

The next four tables help llluminate the importance of the fish business for married women. Table Four reports from whom, if anyone, women got money to start their off-farm, economic actıvity. Table Four shows two important sources of funds: husbands and other women.

Table Five shows that one implication of a woman getting help from her husband in starting an off-farm business is that she is much more likely to be required to hand the proflts over to hlm. We should note that the varlable used is who spent the money, not who particlpated in deciding how to spend the money. The results are clear: if a woman recelved the money to start a 
business from her husband, the husband is much more likely to be the one who spends the profits. It is also revealing that more than a third of the women who started the business without their husbands help also gave them the profits.

\begin{tabular}{|c|c|c|c|}
\hline \multicolumn{4}{|c|}{$\begin{array}{r}\text { TABLE FIVE: RELATIONSHIP BETWEEN RECEIVING HUSBAND'S HELP IN } \\
\text { ACTIVITY AND KEEPING THE MONEY FROM THE ACTIVITY } \\
\text { - WOMEN'S OEF-FARM ECONOMIC ACTIVITIES }\end{array}$} \\
\hline & & \multicolumn{2}{|c|}{$\begin{array}{c}\text { DID WIFE RECEIVE HUSBAND'S HELP WHEN } \\
\text { STARTING THE ACTIVITY? }\end{array}$} \\
\hline & & NO & YES \\
\hline \multirow[t]{3}{*}{ PERSON WHO SPENT THE MONEY } & HUSBAND & $36 \%$ & $85 \%$ \\
\hline & WIFE & $64 \%$ & $15 \%$ \\
\hline & $\mathrm{N}$ & 31 & 39 \\
\hline \multicolumn{4}{|c|}{ 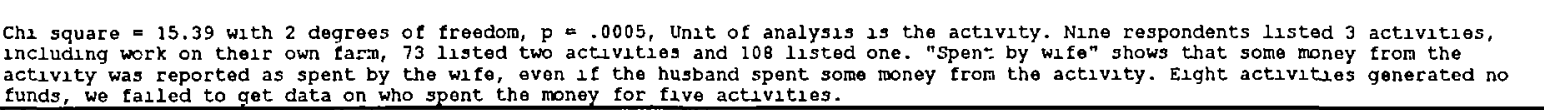 } \\
\hline
\end{tabular}

Two important points should be kept in mind. As many scholars have pointed out, even when the woman spends the money, the husband may be leaving her to care for the household, whlle he spends other money on what he pleases (Potash 1985, Safilos-Rothschild 1990, Smlth and Stevens 1988). Women often subsidize their husband's bachelor goods even when the money is kept in thelr hands. Moreover, Wamalwa (1989) found a pattern among the Wakamba ${ }^{3}$ in Kenya $1 n$ whlch women use thelr surplus for the community, whlle men invest privately, thus increasing gender stratıficatıon. Nevertheless, a woman holding money still has more bargalning power within the household than a woman who does not (Holmboe-ottesen and Wandel 1991).

The other point is one that several women took pains to point out to outside researchers who sometimes seemed intent on asking questions about how terrible their husbands were. It is true that many women on the shores of Lake Victorla are caught in bad marrlages with lazy drunks. It is also true that

Not a people lıving near Lake Vlctorla. 
custom and social structure give men permission, and even encouragement, to behave in repressive and Irresponsible ways vis a vis their families. on the other hand, many women have partnerships in which decisions about the household really are made together. There are also discourses, particularly relıgious ones, that encourage responsıble behavior.

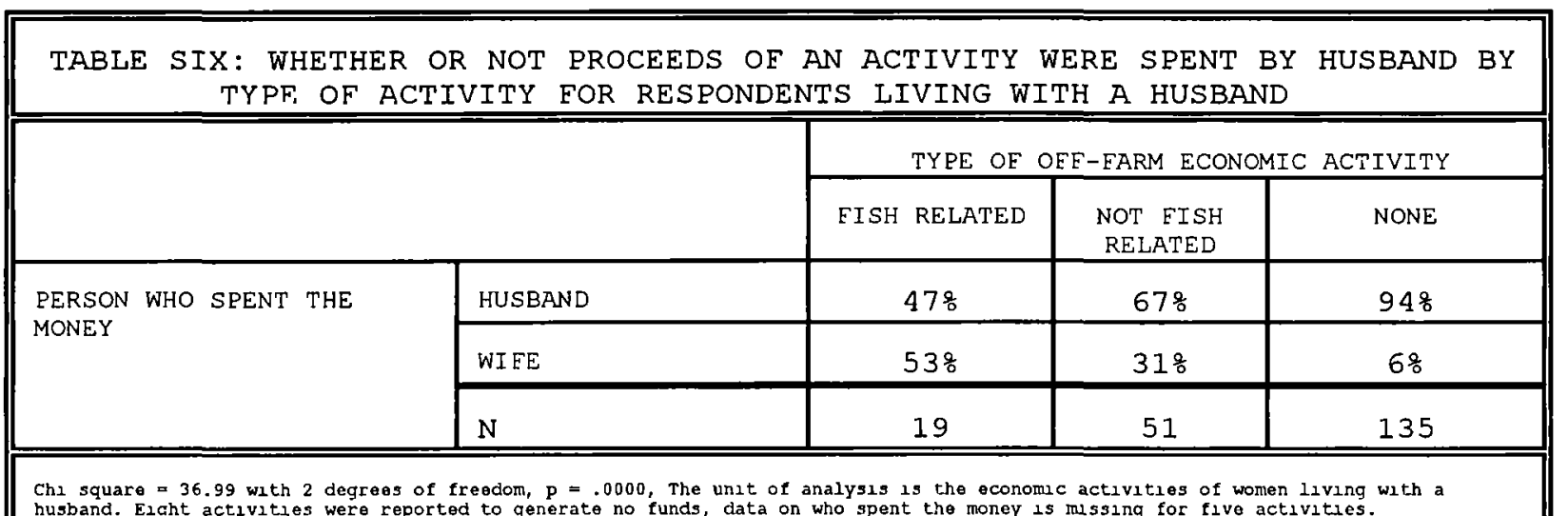
Chi square $=36.99$ with 2 degrees of freedom, $P=.0000$, The unit of analysis 13 the economic activities of women living with a
husband. Elght activities were reported to generate no funds, data on who spent the money is missing for flve activities.

Tables $S i x$ and Seven explore the relatıonship between husbands and types of off-farm economlc activities. Table Six shows two things. The Elrst is that off-farm economic activities in general contribute to women's independent control of resources. The second is that fish-related activities contribute to this independence to a greater degree than do non-fish-related activities.

TABLE SEVEN: RELATIONSHIP BETWEEN RECEIVING HUSBAND'S HELP IN STARTING AN ACTIVITY AND TYPE OF WOMEN'S NON-FARM ECONOMIC ACTIVITY

\begin{tabular}{|c|c|c|c|}
\hline & & \multicolumn{2}{|c|}{ TYPE OE OFE-EARM ACTIVITY } \\
\hline & & EISH & NON-FISH \\
\hline \multirow{3}{*}{$\begin{array}{l}\text { DID WIFE RECEIVED HUSBAND'S } \\
\text { HELP WHEN STARTING THE } \\
\text { ACTIVITY }\end{array}$} & No & $62 \%$ & $37 \%$ \\
\hline & YES & $38 \%$ & $63 \%$ \\
\hline & $\mathrm{N}$ & 21 & 62 \\
\hline
\end{tabular}

Table seven profiles the relationship between the type of off-farm activity and recelving start-up money for that actıvity from a husband. Those 
who are not involved in flsh-related activitıes are more likely to have recelved start-up money from thelr husbands.

Tables Five, Six, and Seven taken together reveal a clear pattern. Women engaged in economlc activities are often operating as their husband's agents. They recelve resources from him and he recelves the proceeds. For reasons that are not entirely clear to us, marrıed women engaged in fısh-related actıvitıes are likely to operate more autonomously. The stronger relationship is between providing capltal and recelving the proceeds. When we test the effects of "fish-related busıness" and "husband as source of capital" on "control of proceeds" together in a logistical regression, only husband as source of capital remans signıfıcant. Husbands for whom wives are playıng the role of an economlc agent seem reluctant to set them up in fish-related businesses.

on possible explanation is surveillance. Fish-related actıvities keep women moving between the flsh landings, processing areas, and marketıng areas. This may reduce the abılity of husbands to survellle the actıvity, at least in comparıson to cooklng and selling rlce cakes or running a store, which are more sedentary. This may discourage husbands from fundıng these activitıes. Years ago, they did not allow women to do any petty tradıng, but now men see it as a source of income (Masaiganah 1992). Fish-related work may be more attractive to women in certaln types of marriages. Gerrard (1992) argued that fish traders in Tarlme tend to be women with more co-wives, older husbands and/or husbands living elsewhere.

The story of Mama Mmoja provides illustratıon.

Mama Mmoja lives in Esegere, a small Muslim fishing community In Tarime District, near the kenya border. She 1530 and has five children. She was married when she was 16 to a man who was already marrled. But she considers herself the first wife because the other woman's parents never recelved a bride price from the husband.

She describes her husband as lazy. He does not farm. He sends his fishing crew out by themselves and spends his own time "choosing where he will go to take his meals."

Her husband set her and her co-wlfe up in a small tea shop close to the fishing beach. Each wife operated the shop in weekly shifts. They were expected to provide for their own consumption from the profits they made during their shift. 
Mama Mmoja turned to her brother in Musoma town for help. Her brother bought her five pressure lamps and five nets for fishing dagaa. She invested this equipment in her husband's fishing operation and this arrangement was successful for a whlle. Then her husband went to flsh on Ukerewe Island and he stayed there for months without sending her share of the proceeds. During the same period the tea shop business folded because neither wife could make the relnvestment necessary to keep in going. They were left to rely entirely on farming.

When her husband returned from Ukerewe he had another wafe who had two chlldren by another man. The fish caught in her fishing nets was supporting the whole family, including her co-wives and their chlldren. She took her five pressure lamps and two fishing nets and now she has rented them to another fisher for what she considers good terms. The other three nets remain with her husband and she conslders this a bad investment because of his laziness. Although she knew she would gain nothing, she declded to leave these nets with him to "comfort" him and Insure peace in the famlly.

Turning again to her brother, Mama Mmoja got enough money to start the hotel busıness again. Her brother had also agreed to take her firstborn so that she could go to primary school. When she completed primary school, the brother wanted to continue to help her go to secondary school. Her husband refused and sent a letter to the brother demanding his daughter's return. When she returned, he married her to a man of 46 in return for a bride price of 10 cows, 5 goats, and 30 dollars. "I was confused" she sald "and my daughter had to agree for fear of her father. I cried because my daughter was very young and without an education probably will not be able to help me nor herself."

For Mama Mmoja, a woman caught in a terrible marıtal situatıon, access to flshing is an important resource. She needed to be able to have several different ways of protecting her own and her children's llvelıhood. Fishıng was another avenue that she could use. It gave her a measure of independence and flexiblilty in dealing with her husband, and proved an lmportant bargaınıng chip.

\section{Conclusion}

Changes in the Lake Victoria ecosystem have increasingly margunalızed economic opportunities avallable to women. This is not because of the changes themselves. It results from their lack of power in the day to day negotiations that determine how lake-side people will respond to the changes. Women have experlenced a loss of access to the traditional specles that they once processed, and even flshed for, while gaining access to the newer species has proved difficult. They have been faced with greater need for capital, 
powerful competition for fish procurement, and even the actıve resistance of men. Areas that they have carved out for themselves in the new flsherles, flsh racks and swim bladders, are now belng threatened. The fisherles management measures that are golng into place are maklng it more difflcult for them to get fish.

These women are not giving up. Their responses are Increasingly articulated at the community level. They help each other, often almost in splte of outside efforts to get them to do so. WhIle revolving credit groups have been slower to start on the lake than elsewhere, they are coming into being. They offer precisely what the women need to deal with the new fisheries - Elexible access to credit.

Access to the fish Is very important to these women. It is not simply another economic option, although that alone would be very 2 mportant. Fish are a resource that provides greater economic Independence than others do. The fish business is an alternative to agriculture for single women with diminished access to land and other Inputs, and It is an avenue of Increased independence for married women. 
Barel, C.D.N. 1986

The Decline of Lake Victoria's Clchlid Species Flock University of Leıden: Zoologisch Laboratorium

Bwathondl, P.O.J. and O. Mosille 1988

"The Handling, Processing and Marketing of Nıle Perch in Tanzania" in Technical Reports presented at the project seminar on Improved Utilization of the Nile Perch Kisumu, Kenya 28-31 March, Rome: FAO

Bundy A. and T. Pltcher 1995

"An analysis of species changes in Lake Victoria: did the Nıle perch act alone?" pp 111-136 in Pltcher, T.J. and P.J.B. Hart (Eds) The Impact of Species Changes in Afrlcan Lakes London: Chapman and Hall, Fish and Fisheries Series No. 18

Croll, E.J. 1981

"Women in Rural Production and Reproduction in the Soviet Unıon, China, Cuba, and Tanzania: Soclalıst Development Experıences" Signs 7:361-374

Dobbs, C.M. 1927

"Fishing in the Kavirondo Gulf, Lake Victorla" Journal of the East Africa and Uganda Natural History Society 30 (July):97-109

Fortmann, L. 1979

"Women and Tanzanıa Agrıcultural Development" Pp. 278-287 in Kim, K.S., R.B. Mabele, and M.J. Schultheis (Eds) Rapers on the Political Economy of Tanzania Nalrobl: Helnemann Educational Books Ltd.

Gerrard S. 1990

"Women, Soclal Organization and Production of Knowledge: Challenges of Fisheries Development" Paper presented at the Confrence on Socio-Economic Condıtıons for Develoment of Artisanal Fısheries in Afrıca Tromso, Norway 15-17 June

Gerrard, S. 1992

"Clans, Gender and Kılns" Pp. 223-246 in stolen, K.A. and M. Vas Gender and Change in Developing Countrles Olso: Norweglan University Press

Glddens, A. 1984

The Constitution of Soclety Berkeley: Unıversity of California Press

Harrıs, C.K., D.E. Wiley, and D.C. Wilson 1995

"Distributional and Redistributional Impacts of Lake Victoria species Introductions" in in Pltcher, T.J. and P.J.B. Hart (Eds) The Impact of Specles Changes in Afrlcan Lakes London: Chapman and Hall, Flsh and Fisheries Serles No. 18

Holmboe-ottesen, G. and M. Wandel

"Wife, Today I Only had Money for Pombe" Pp. 93-119 in Stolen, K.A. and M. Vas Gender and Change in Developing Countrles Norweglan University Press 
Kazımoto, S. 1991

"The Role of Moegani FDC to the Artisinal Fisheries in Mara Region" paper presented at a Workshop on Artisinal Fishermen Training and Extension Servies in Mara Region, 16-20 December

Leendertse, K. 1990

"Introductory Paper: Women in Tanzanian Inland Fisherıes" Paper presented at the Workshop on Enhanced Women's Participation in Fishery Development, Zimbabwe, 4-7 Dec. 1990 UNDP/EAO-RAF/87/099 (IFIP)

Maembe, T. W. 1990

"A Review of the Main Characterıstıcs of Long Distance Fısh Trade from Lake Vlctoria, Tanzania" Pp 68-100 in Rroceedings of the Symposium on Socio-Economic Aspects of lake Vlctoria Flsheries Vol.1. UNDP/EAO Regional Project for Inland Fisheries Planning (IFIP) $\mathrm{RAF} / 87 / 099-\mathrm{WP} / 05 / 90114 \mathrm{pp}$

Masalganah, M.S. 1992

Interview at the Mbegani Elsherles Development Center in Bagamoyo, August

Mbilinyı, M. 1990

"'Structural Adjustment', Agrıbusıness and Rural Women in Tanzania" Pp. 111-124 in Bernstein, H., B. Crow, M. Mackintosh and C. Martin (Eds) The Food Question: Rrofits Versus People New York: Monthly Review Press

McCall, M. 1987

"Carrying heavier burdens but carryıng less weight: some implicatıons of villagization for women in Tanzania" Chapter 7 Pp. 192-214 in Momsen, J.H. and J.G.Townsend (Eds) Geography of Gender in the Third World Hutchinson: SUNY Press

Okeyo, A.P. 1980

"Daughters of the Lakes and Rivers: Colonization and the Land Rights of Luo Women" Pp. 186-213 in Etienne, M. and E. Leacock (Eds) Women and Colonization: Anthropologlcal Perspectives Praeger

Potash, B. 1985

"Female Farmers, Mothers-in-law and Extension Agents: Development Plannin and a Rural Luo Community" Working Paper \#90 Michigan State University, Women in Development office

Reynolds, J.E. and D.F. Gréboval 1988

Socio-Economic Effects of the Evolution of Nile Perch Elsheries in Iake Victoria: a Review FAO Rome: CIFA Technical Paper \#17:148 Pp.

Reynolds J.E., D. Gréboval and P. Mannini 1992

Thirty Years on: Observation on the Development of the Nile Perch Elshery ln Lake Victoria UNDP/FAO Reglonal Project for Inland Fisheries Planning (IFIP)

RTF2 (Reglonal Task Force 2) 1995

Report on Management of Water ouality and Land Use Including Wetlands Lake Victorıa Environmental Management Programme

Scudder, T. and Conelly, T. 1985

"Management Systems of Riverine Fisherles" EAO Fisheries Techlcal Paper No 263 Rome: FAO 
Smlth, C.D. and L. Stevens 1988

"Farming and Income-Generation in the Female-headed Smallholder Household: The Case of a Haya Village in Tanzania" Canadian Journal of African Studies 22: 552-566

Staudt, K. and J.M. Col 1991

"Diversity in East Afrıca: Cultural Pluralısm, Publıc Policy, and the state" Pp. 241-264 in Gallin, R.S. and A. Ferguson (Eds) The Women and International Development Annual Volume 2 Boulder: Westview

Thomas, B. P. 1988

"Household Stategies for Adaptation and Change: Partıcipation In Kenyan Rural Women's Assoclatıons" Working Paper \#165 Michigan State

Unlversity, Women in Development offlce

Thompson, P. 1985

"Women in Fishlng - the Roots of Power between the Sexes" Comparatıve studies in Soclety and History $27: 3-32$

Udvardy, M. 1988

"Women's Groups Near the Kenyan Coast: Patron-Clıentship in the Development Arena" Pp. 217-235 in Brokensha, D. W. and P.D. Little (Eds) Anthropology of Development and Change in East Africa Boulder: Westvlew

Wamalwa, B.N. 1989

"Indigenous Knowledge and Natural Resources" Pp. 45-68 in Kırıro, A. and $\mathrm{C}$. Juma (Eds) Gaining Ground: Institutional Innovations in Land-use Management in Kenya Nalrobl: ACTs Press

Wlison, D.C and M. Medard 1995

"Implications for Fisherıes Management of the Changing situatıon in Lake Victoria Fishing Communities" forthcoming in African Rural and Urban studies

Yongo, E. O. 1991. "Socio-economic Aspects of Fish Utılızation and Marketing" Kisumu: Kenya Marıne Fisherıes Research Institute, P.O. Box 1881: Mimeo 